Review

\title{
miR-497 expression, function and clinical application in cancer
}

\author{
Gang Yang ${ }^{1, *}$, Guangbing Xiong ${ }^{1, *}$, Zhe $\mathrm{Cao}^{1, *}$, Suli Zheng ${ }^{1}$, Lei You ${ }^{1}$, Taiping Zhang ${ }^{1}$ \\ and Yupei Zhao ${ }^{1}$ \\ ${ }^{1}$ Department of General Surgery, Peking Union Medical College Hospital, Chinese Academy of Medical Sciences and Peking \\ Union Medical College, Beijing, China \\ * These authors contributed equally to this work \\ Correspondence to: Taiping Zhang, email: tpingzhang@yahoo.com \\ Yupei Zhao, email: zhao8028@263.net
}

Keywords: miR-497; carcinogenesis; biomarker; clinical application

Received: April 01, $2016 \quad$ Accepted: June 06, 2016

Published: June 17, 2016

\section{ABSTRACT}

MicroRNAs (miRNAs) are small non-coding RNAs that inhibit gene expression by binding to the $3^{\prime}$ untranslated region ( $3^{\prime}$-UTR) of their target mRNAs. Recent studies show that miR-497 plays an important role in various cancers. Here, we summarize the existing studies of miR-497 as following: (1) miR-497 expression in cancer; (2) regulation mechanisms of miR-497 expression; (3) function of miR-497 in cancer; (4) direct targets of miR-497; (5) clinical applications of miR-497. Recent analyses verify that miR-497 mainly suppresses tumors; however, it also acts as an oncogene in several cancers. Increasing evidence indicates that miR-497 can serve as a diagnostic and prognostic biomarker and is a promising therapeutic target for future clinical applications.

\section{INTRODUCTION}

MicroRNAs (miRNAs) comprise a class of small non-coding RNAs of 19-25 nucleotides [1].They are transcribed as a primary miRNA (pri-miRNA) and processed in the nucleus by Drosha to form an $\sim 70$-nt precursor miRNA (pre-miRNA) [2]. Then, the premiRNA is transported to the cytoplasm by exportin- 5 and further processed by Dicer and TRBP2 to generate an imperfect mature miRNA: miRNA* duplex [35]. After the miRNA duplex is separated, the mature miRNA molecule is incorporated into the RNA-induced silenced complex (RISC) where it binds to a member of the Argonaute (AGO) protein family. The other transient strand, miRNA*, is usually degraded by AGO2 $[6,7]$. The active RISC complex then binds to a mRNA transcript with a complementary sequence to inhibit it at the posttranscriptional level [8]. miRNA dysregulation is involved in the initiation and progression of various diseases [9].

miR-497, a highly conserved miRNA encoded by the first intron of the MIR497HG (Gene ID: 100506755) gene on human chromosome 17p13.1 [10], belongs to the miR-15 family (miR-15a, miR-15b, miR-16-1/2, miR-195, miR-424 and miR-497), sharing the same 3'-UTR binding seed sequence AGCAGCA [11]. The characteristics of some miR-15 family members, including miR-15, miR-16 [12] and miR-195 [13], have been summarized elsewhere; therefore, we focused on the most recent findings regarding miR-497. miR-497 is found in almost all human organs and tissues, including the brain [14], breast [15], lung [16], kidney [17], stomach [18], liver [9] and blood [19]. Several studies have confirmed its involvement in human disease. To better understand the role of miR-497 in cancers, we summarize recent studies investigating the expression, regulatory, biological functions, targets and clinical value of miR-497. Our goal is to provide useful information for miR-497 future clinical applications.

\section{EXPRESSION OF MIR-497 IN CANCER}

The first indication of miR-497 dysregulation was based on an investigation of global miRNA expression profiles in primary breast cancer [20]. Decreased miR497 expression in breast cancer was verified in subsequent studies [15, 21-23]. A recent study that profiled miRNAs in male breast cancer found that miR-497 was among the most prominently down-regulated miRNAs [24]. Pinto et al. observed that in familial breast cancer, miR-497 
was statistically significantly over-expressed in males ( $n$ $=23, p=0.008$ ) compared with females [25]. miR-497 down-regulation has also been consistently demonstrated in a variety of other tumor types, including gastric cancer (GC) [26], colorectal cancer (CRC) [27], hepatocellular carcinoma (HCC) [28], pancreatic cancer [29], adrenocortical carcinoma (ACC) [30], bladder cancer [19], non-small cell lung cancer (NSCLC) [16], melanoma [31], ovarian cancer (OC) [32], and cervical cancer (CC) [33] and other solid tumors. These results suggest that miR497 has a tumor-suppressive role. miR-497 expression levels in most cell lines of these types of cancer are also decreased. (The specific expression of miR-497 in cancers is shown in Table 1.)

Although Jiang et al. reported that the miR-497 level was increased in $25 \mathrm{CRC}$ tumor tissues compared with adjacent normal tissues from the same patient [34], Guo et al. [35] confirmed miR-497 down-regulation in 107 of 137 paired samples from 10 CRC patients. Wang et al. found significantly lower miR-497 expression levels in CRC tumor tissues than in adjacent normal tissues [36]. We speculate that this discrepancy regarding miR-497 expression may be related to technical variations in the miRNA isolation methods or different patient states, such as before or after chemotherapy. For example, Qiu et al. revealed that bufalin treatment could increase the miR-497 level in HCT116 CRC cells [37]. Nonetheless, in a study of $184 \mathrm{CC}$ patients, 186 cervical intraepithelial neoplasia (CIN) patients and 193 healthy controls [38], serum miR-497 was significantly increased $(\mathrm{P}<0.001)$ in $\mathrm{CC}$ patients, which is inconsistent with the down-regulation of miR-497 in tumor tissues [33]. Thus, it is possible that tumor cells are not a major contributor to elevated circulating miR-497 levels. Further studies should explore the potential effects of disparate miR-497 expression on CC development.

More recent studies have shown that miR-497 is up-regulated in several other cancers. In the leukemic cells of subset \#4 cases, miRNAs expression profiling revealed significant up-regulation of miR-497 in CD19+ cells compared with the normal B-cell population in chronic lymphocytic leukemia (CLL) [39]. miR-497 is also over-expressed in glioma [40] and diffuse large B-cell lymphoma (DLBCL) [41]. These findings indicate that miR-497 may have different roles in tumorigenesis.

\section{REGULATION MECHANISMS OF MIR-497 EXPRESSION}

\section{Transcription factors}

Transcription factors (TFs) mainly bind to specific DNA sequences through multiple mechanisms, either promoting or repressing miRNA transcription [42].
Hypoxia-inducible factor- $1 \alpha(\mathrm{HIF}-1 \alpha)$ is a key TF induced by hypoxia and can increase the expression of many genes [43, 44]. Although miR-497 expression is decreased in retinoblastoma cells under hypoxic conditions [45], Lan et al. discovered that hypoxia and DOMG, a well-established agent that induces HIF-1 $\alpha$, significantly increased pri-miR-497 levels [40]. The authors also used chromatin immunoprecipitation (ChIP) assays to demonstrate that HIF-1 $\alpha$ binds to HRE1 elements. The hypoxia-induced increase in luciferase activity was significantly inhibited with a mutated HRE1 in the core binding site; this eliminated HIF- $1 \alpha$ binding and indicated that HIF- $1 \alpha$ activates miR-497 transcription by directly binding to the HRE1 element upstream of the promoter. Wu et al. confirmed that miR-497 over-expression could decrease the hypoxia-induced increase in HIF- $1 \alpha$ protein levels [46]. Therefore, miR-497 and HIF-1 $\alpha$ form a negative feedback loop, as Figure 1 shows.

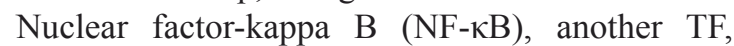
participates in various biological processes with pleiotropic activity and in the expression of many genes and miRNAs when present in the nucleus in its active form $[47,48]$. Wei et al. observed that p65 (also known as Rel A, the active subunit of $\mathrm{NF}-\kappa \mathrm{B}$ ) can directly bind to a specific miR-497 promoter site in C2C12 myoblast cells and reduce its expression, as determined by luciferase and ChIP-PCR assays [49]. However, Mechtler et al. reported that PIPK-1 and IL-1 $\beta$, which activate NF- $\kappa$ B, can increase the miR-497 level [50], though the direct relationship between miR-497 and NF- $\kappa$ B and the miR-497 gene NF$\kappa \mathrm{B}$ binding site was not exhaustively described. Hence, we speculate that the effect of PIPK-1 and IL-1 $\beta$ on miR-497 expression may occur in an NF- $\mathrm{KB}$-independent manner.

\section{Epigenetic alterations}

Similar to protein-coding genes, miRNAs undergo epigenetic modulation [51].

Indeed, DNA methylation at $\mathrm{CpG}$ dinucleotides can affect miRNAs expression [52]. For example, Wiklund et al. found that miR-497 was silenced concomitantly with DNA hypermethylation of CpGs in the upstream region of the miR-497 promoter in breast cancer tissues and cells [15]. Furthermore, Cai et al. reported that betaine, a methyl provider that can modulate gene expression through DNA methylation [53-56], led to a significant reduction in hepatic miR-497 expression in newborn piglets when administered to their mothers during gestation. This finding indicates a strong association between DNA methylation and miR-497 levels [57]. Additionally, Menigatti et al. showed that treatment with the DNA-demethylating agent 5-aza-2-deoxy-cytidine (5-Aza-dC) could restore miR-497 expression, which is suppressed in HT29 CRC cells [27]. Furthermore, the $\mathrm{CpG}$ island upstream of the transcription start site (TSS) for miR-497 was found to be monoallelically methylated 
Table 1: The expression, targets, biological functions and role of miR-497 in cancer.

\begin{tabular}{|c|c|c|c|c|c|c|}
\hline cancer type & expression & \begin{tabular}{|l|} 
site (tissue/plasma/ \\
cell)
\end{tabular} & targets & biological functions & role & reference \\
\hline breast cancer & down & tumor and cell line & $\begin{array}{l}\text { Bcl-w,Raf1,Ccnd1,cyclin } \\
\text { E1,Bcl-2,VEGF,VEGFR2 and } \\
\text { HIF-1 } \alpha\end{array}$ & $\begin{array}{l}\text { inhibit angiogenesis, cell } \\
\text { cycle, colony formation, } \\
\text { proliferation, metastasis } \\
\text { and invasion ; increase } \\
\text { early apoptosis }\end{array}$ & $\begin{array}{l}\text { tumor } \\
\text { suppressor }\end{array}$ & $\begin{array}{l}{[15,22,} \\
46, \quad 66, \\
69,81]\end{array}$ \\
\hline gastric cancer & down & tumor and cell line & BCL2,eIF4E & $\begin{array}{l}\text { inhibit G1/S transition, } \\
\text { proliferation, invasion; } \\
\text { inhibit tumor growth } \\
\text { and metastasis in vivo; } \\
\text { sensitize anticancer drugs }\end{array}$ & $\begin{array}{l}\text { tumor } \\
\text { suppressor }\end{array}$ & {$[18,26$} \\
\hline \multirow{2}{*}{$\begin{array}{l}\text { colorectal } \\
\text { cancer }\end{array}$} & down & tumor and cell line & IGF1-R,KSR1 & $\begin{array}{l}\text { reduce cell proliferation, } \\
\text { invasion and migration }\end{array}$ & $\begin{array}{l}\text { tumor } \\
\text { suppressor }\end{array}$ & {$[35,36]$} \\
\hline & up & tumor & Nrdp1 & increase cell invasiveness & $\begin{array}{l}\text { tumor } \\
\text { promoter }\end{array}$ & {$[34]$} \\
\hline $\begin{array}{l}\text { primary } \\
\text { peritoneal } \\
\text { carcinoma }\end{array}$ & down & tumor & - & - & - & {$[60]$} \\
\hline $\begin{array}{l}\text { hepatocellular } \\
\text { carcinoma }\end{array}$ & down & tumor and cell line & $\begin{array}{l}\text { CCNE1,CDC25A,CCND3, } \\
\text { CDK4,BTRC,CHEK1,VEGFA } \\
\text { and AEG-1 }\end{array}$ & $\begin{array}{lrr}\text { inhibit } & \text { cell } & \mathrm{G} 1 / \mathrm{S} \\
\text { transition, } & \text { proliferation } \\
\text {, angiogenesis } & \text { and } \\
\text { metastasis; } & \text { repress } \\
\text { microvessel } & \text { densities, } \\
\text { metastasis in vivo } & \\
\end{array}$ & $\begin{array}{l}\text { tumor } \\
\text { suppressor }\end{array}$ & $\begin{array}{l}{[28,58} \\
67,89]\end{array}$ \\
\hline $\begin{array}{l}\text { pancreatic } \\
\text { cancer }\end{array}$ & down & tumor and cell line & IGF-1R,FGF2 and FGFR1 & $\begin{array}{l}\text { suppress cells } \\
\text { proliferation, cycle, } \\
\text { migration and invasion; } \\
\text { enhance apoptosis and re- } \\
\text { sensitize cells }\end{array}$ & $\begin{array}{l}\text { tumor } \\
\text { suppressor }\end{array}$ & {$[29,64]$} \\
\hline $\begin{array}{l}\text { adrenocortical } \\
\text { carcinoma }\end{array}$ & down & tumor & TARBP2 and DICER & $\begin{array}{l}\text { reduce cell proliferation; } \\
\text { increase apoptosis }\end{array}$ & \begin{tabular}{|l} 
tumor \\
suppressor
\end{tabular} & {$[30,96]$} \\
\hline $\begin{array}{l}\text { renal cell } \\
\text { carcinoma }\end{array}$ & down & tumor and cell line & - & \begin{tabular}{|l} 
inhibit proliferation, \\
migration and invasion
\end{tabular} & \begin{tabular}{|l} 
tumor \\
suppressor
\end{tabular} & {$[17]$} \\
\hline bladder cancer & down & plasma and tumor & BIRC5 and WNT7A & \begin{tabular}{|l} 
inhibit proliferation, \\
migration and invasion
\end{tabular} & \begin{tabular}{|l} 
tumor \\
suppressor
\end{tabular} & {$[10,19]$} \\
\hline prostate cancer & down & cell line and serum & IKK beta & $\begin{array}{l}\text { inhibit proliferation, } \\
\text { migration and invasion; } \\
\text { induce apoptosis }\end{array}$ & $\begin{array}{l}\text { tumor } \\
\text { suppressor }\end{array}$ & {$[70,95]$} \\
\hline lung cancer & down & tumors and cell lines & $\begin{array}{l}\text { HDGF,CCNE1,VEGF-A, } \\
\text { YAP1 }\end{array}$ & $\begin{array}{l}\text { inhibit cell proliferation, } \\
\text { invasion and colony } \\
\text { formation; inhibit tumor } \\
\text { growth in vivo }\end{array}$ & $\begin{array}{l}\text { tumor } \\
\text { suppressor }\end{array}$ & $\begin{array}{l}{[16,71,} \\
90,102]\end{array}$ \\
\hline \multirow[b]{2}{*}{ cervical cancer } & down & tumor and cell line & IGF-1R,MEK1 & $\begin{array}{l}\text { suppress migration and } \\
\text { invasiveness; induce } \\
\text { apoptosis }\end{array}$ & $\begin{array}{l}\text { tumor } \\
\text { suppressor }\end{array}$ & {$[33,97]$} \\
\hline & up & serum & - & $\begin{array}{l}\text { promote apoptosis and } \\
\text { inhibit proliferation; } \\
\text { suppress tumor growth in } \\
\text { vivo }\end{array}$ & $\begin{array}{l}\text { tumor } \\
\text { suppressor }\end{array}$ & {$[38]$} \\
\hline ovarian cancer & down & tumor and cell line & $\begin{array}{l}\text { VEGF-A, SMURF1, mTOR/ } \\
\text { P70S6K1 }\end{array}$ & $\begin{array}{l}\text { suppress angiogenesis, } \\
\text { migration and invasion }\end{array}$ & $\begin{array}{l}\text { tumor } \\
\text { suppressor }\end{array}$ & \begin{tabular}{|ll}
{$[59$,} & 68, \\
$98]$ & \\
\end{tabular} \\
\hline retinoblastoma & down & tumor and cell line & WEE1 & $\begin{array}{l}\text { reduce cell viability and } \\
\text { increase apoptosis }\end{array}$ & $\begin{array}{l}\text { tumor } \\
\text { suppressor }\end{array}$ & {$[45,99]$} \\
\hline $\begin{array}{l}\text { the head and } \\
\text { neck squamous } \\
\text { cell carcinoma }\end{array}$ & down & tumor and plasma & ANLN and HSPA4L & $\begin{array}{l}\text { suppress cell proliferation, } \\
\text { migration; induce } \\
\text { apoptosis; inhibited tumor } \\
\text { growth in vivo }\end{array}$ & $\begin{array}{l}\text { tumor } \\
\text { suppressor }\end{array}$ & {$[65]$} \\
\hline glioma & up & tumor and cell line & PDCD4 & $\begin{array}{l}\text { suppress apoptosis; } \\
\text { reduce sensitivity of } \\
\text { chemotherapy }\end{array}$ & $\begin{array}{l}\text { tumor } \\
\text { promoter }\end{array}$ & {$[40]$} \\
\hline melanoma & down & tumor and cell line & - & $\begin{array}{l}\text { inhibit proliferation and } \\
\text { viability }\end{array}$ & \begin{tabular}{|l} 
tumor \\
suppressor
\end{tabular} & {$[31,109]$} \\
\hline osteosarcoma & down & tumor and cell line & VEGF-A, AMOT & $\begin{array}{l}\text { suppress proliferation and } \\
\text { invasion; re-sensitize cell }\end{array}$ & $\begin{array}{l}\text { tumor } \\
\text { suppressor }\end{array}$ & {$[72,100]$} \\
\hline
\end{tabular}




\begin{tabular}{|l|l|l|l|l|l|l|}
\hline leukemia & up & leukemic cells & BCL2 & increase apoptosis & $\begin{array}{l}\text { tumor } \\
\text { suppressor }\end{array}$ & {$[39,107]$} \\
\hline
\end{tabular}

Note: The expression of miR-497 is contradictory in colorectal cancer tissues and discrepant between tumor tissues and serum in cervical cancer.

in 50/50 samples from normal colorectal mucosa but fully methylated in 38/50 (76\%) samples from colorectal adenomas. Additionally, miR-497 expression decreased significantly in the colorectal adenomas, suggesting that the miR-497 locus might be methylation imprinted during colorectal tumorigenesis. Recently, miR-497 was also found to be down-regulated in HCC [58] and OC [59] as a result of hypermethylation of the promoter region.

Although these studies have established that DNA methylation regulates miR-497, other regulatory mechanism of epigenetic alterations, such as histone modification and genomic imprinting have not been reported yet. More research is needed.

\section{Genomic alterations}

In addition to TFs and epigenetic modification, genomic alterations have also been reported to control miR-497 expression in cancer cells. For example, using array comparative genomic hybridization (aCGH), Guo et al. found that the segment of chromosome 17p13.1 that harbors miR-497 is deleted in colon cancer samples with lower miR-497 expression compared with normal mucosa [35]. In a large cohort of 131 paired CRC tissues, $\sim 71 \%$ of colon cancers exhibited DNA copy number reduction at this segment. The fact that colon cancer samples lacking this fragment have lower miR-497 levels than cancer samples that retain the fragment indicates that the observed gene copy number reduction is directly responsible for miR-497 decrease. Consistently, Flavin et

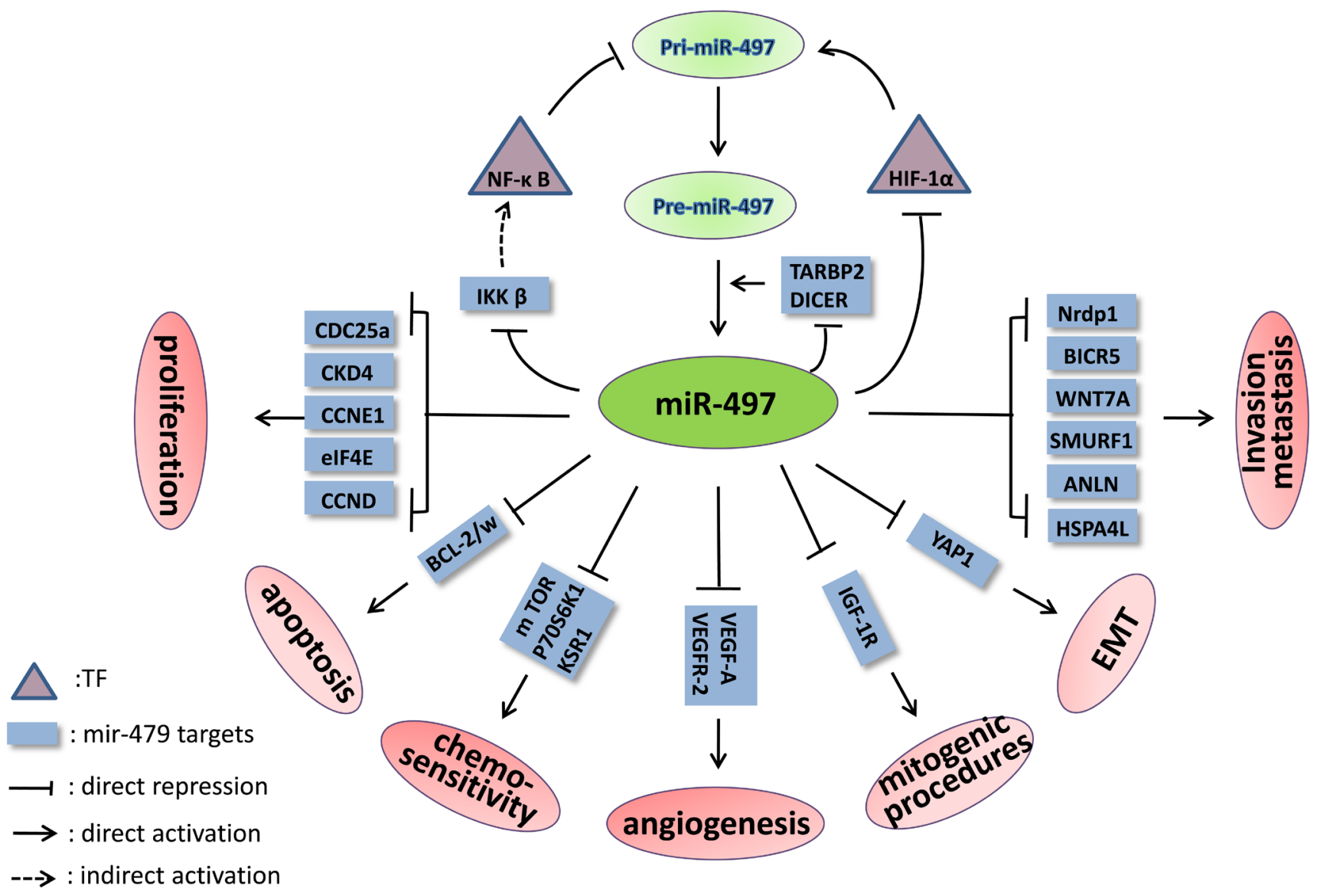

Figure 1: The signaling pathways and feedback loops in which miR-497 is involved. The feedback loops of miR-497-HIF-

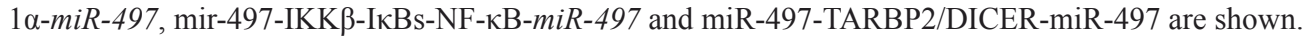


al. reported that miR-497 down-regulation may be caused by distinct allelic loss patterns in peritoneal carcinoma cells [60], whereas Vaishnavi et al. found that miR-497 upregulation in autism is correlated with a duplicated copy number variation (CNV) locus [61].

Furthermore, recent studies reported that long noncoding RNAs (lncRNAs), which can bind and sequester miRNAs and act as so-called miRNAs sponges, could inhibit miR-497 expression [62, 63]. However, no study to date has reported a relationship between lncRNAs and miR-497.

\section{FUNCTION OF MIR-497 IN CANCER}

Both gain- and loss-of-function approaches are commonly utilized to examine miR-497 function. The following studies based on these methods support an anti-oncogenic role for miR-497. Several studies have reported that increasing miR-497 expression via premiR-497 transfection suppresses proliferation and increases apoptosis in ACC [30] and pancreatic cancer [64] and inhibits migration and invasion in bladder cancer [10] and nasopharyngeal carcinoma [65]. Additionally, miR-497 over-expression was found to block G0/G1 phase transition in MCF-7 breast cancer cells [66] and induce G1/S arrest in SGC-7901 GC cells [26]. miR497 up-regulation by lentivirus LV-miR-497 transfection also significantly represses tumor angiogenesis in HCC [67] and OC [68]. Conversely, the inhibition of miR-497 expression by an miR-497 inhibitor increased the growth and colony formation ability of breast cancer cells but reduced their apoptosis [69]. Moreover, decreases in miR497 led to increased migration and invasion capacities in prostate cancer cells [70], proliferation in NSCLC [71] and chemoresistance in osteosarcomas [72]. Our lab found that in pancreatic cancer, enhanced miR-497 could suppress cell proliferation, induce cycle arrest, attenuate migration and invasion capacities and inhibit tumor growth in vivo $[29,64]$.

In addition to a tumor suppressor role, miR-497 may also act as an oncogene. Lan et al. discovered that miR497 over-expression protects tumor cells from apoptosis and enhances resistance to temozolomide in glioma [40]. Interestingly, when miR-497 expression was increased, the ability to metastasize was abolished in HCT116 CRC cells [35] but enhanced in Caco-2 CRC cells [34]. Such results may be explained by differences in the cell lines.

Therefore, miR-497 largely functions as a tumor suppressor in cancer, but it also acts as an oncogene by inhibiting or activating multiple biological processes, including division, proliferation, apoptosis, angiogenesis, migration, and invasion.

\section{DIRECT TARGETS OF MIR-497}

miRNAs inhibit target gene expression primarily by binding to the 3'-UTRs of target mRNAs, leading to mRNA cleavage or translational repression $[73,74]$. Some miR-497 targets that have been fully validated are discussed below.

B cell lymphoma w (Bcl-w) and Bcl-2 are members of the Bcl-2 family and key regulators of cell apoptosis [75]. They are the primary miR-497 targets. Lei et al. found that Bcl-w reduced apoptosis in tumor cells and that miR-497 could significantly inhibit its expression at both the mRNA and protein levels in breast cancer [66]. Yin et al. used a luciferase reporter assay to demonstrate that miR-497 could directly bind to the 3'-UTR of Bcl-w [76]. In addition, Bcl-2, an anti-apoptosis factor that contributes to tumorigenesis and chemoresistance, was found to be a target of miR-497 in breast cancer [69], GC [77] and CLL [39]. Bcl-w and Bcl-2 also promote the migration and invasion of cells by stimulating downstream factors, including phosphoinositide 3-kinase (PI3K)/ AKT, epidermal growth factor receptor (EGFR), matrix metalloproteinase (MMP)-2, and urokinase-type plasminogen activator (uPA) [78]. Clearly, Bcl-w and Bcl2 are involved in the anti-cancer effect of miR-497.

Vascular endothelial growth factor A (VEGF-A) is the most potent angiogenic factor. It is responsible for angiogenesis via a VEGF receptor 2 (VEGFR-2)dependent signaling pathway [79] and is important for tumor growth, invasiveness and metastasis [80].miR-497 regulation of VEGF-A expression has been confirmed in several cancers. Recent studies have revealed that VEGF-A is a critical target that controls miR-497 repression of tumor growth and invasion in non-small lung cancer [71] and angiogenesis and metastasis in HCC [67]. Shao et al. revealed that VEGF-A over-expression induced by miR497 inhibitors increased the protein level of phosphoAKT, which subsequently up-regulates Bcl- 2 and Cyclin D 1 (CCND1) protein and promoted cell growth in SAOS-2 osteosarcoma cells [72]. Additionally, Wang et al. demonstrated that levels of AKT and extracellular signal-regulated kinase 1/2 (ERK1/2), signaling molecules downstream of VEGF-A, are significantly decreased in miR-497-transfected OC cells, which inhibits angiogenesis [68]. Interestingly, Tu et al. discovered that miR-497 also targets VEGFR-2 to inhibit HUVEC apoptosis and tumor angiogenesis in breast cancer [81]. These results suggest that miR-497 may inhibit angiogenesis and tumor growth by reducing VEGF-A and VEGFR-2 expression through $\mathrm{PI} 3 \mathrm{~K} / \mathrm{AKT}$ and mitogen-activated protein kinase (MAPK)/ ERK pathways. Therefore, VEGF-A and VEGFR-2 may be key mediators of the miR-497 anti-angiogenesis effect on tumor progression.

Insulin-like growth factor receptor 1 (IGF-1R), a transmembrane tyrosine kinase, can activate multiple signaling pathways to control mitogenic procedures when bound to a ligand [82-84]. Recent studies showed that miR-497 targeted IGF-1R to inhibit proliferation, invasion and metastasis by regulating PI3K/AKT signaling pathway 
activation in colorectal cancer [35] and to function as an oncogene in cervical cancer [33]. Additionally, our lab demonstrated that suppressed IGF-1R protein expression via miR-497 up-regulation was able to re-sensitize pancreatic cancer cells to gemcitabine and that plasma IGF-1R can discriminate pancreatic cancer from other pancreatic tumors [64]. Furthermore, insulin receptor (IR), which mediates similar downstream signaling pathways as IGF-1R, has also been verified as an miR-497 target, and it plays an important role in myogenesis [49] and metabolic regulation [85]. Such studies indicate that miR-497-IGF$1 \mathrm{R} / \mathrm{IR}$ is likely a clinically significant tumor suppressoroncogene pair in human carcinomas and a critical mediator of normal biological functions.

Cyclin E1 (CCNE1) is a member of the cyclin family. It binds to and activates cyclin-dependent kinase 2 (CDK2) to promote cell cycle progression from the G1 to the $\mathrm{S}$ phase by initiating a cascade of events $[86,87]$. Over-expression of CCNE1 has been detected in various cancers [88], and recent studies have revealed that miR497 can directly reduce the CCNE1 protein level to suppress tumor growth by inducing G1 arrest in breast cancer [22] and HCC [89]. Han et al. discovered that when CCNE1 was knocked down, the inhibitory effect on cell proliferation was not enhanced by miR-497 overexpression in lung cancer, indicating that CCNE1 mediates the effects of miR-497 on cell growth [90]. Several other genes encoding cell cycle activators, including cyclins [15, 91], cyclin-dependent kinase 4 (CDK4) [89], eukaryotic translation initiation factor 4E (eIF4E) [26] and cell cycle division factors (CDC25a) [92], are also known targets of miR-497.

Inhibitors of NF- $\kappa$ B kinase $\beta$ (IKK $\beta$ ), which is the key kinase in the canonical NF- $\kappa \mathrm{B}$ signaling pathway, is involved in cell proliferation, metastasis, invasion and the epithelial-mesenchymal transition (EMT) [93]. IKK $\beta$ can promote the translocation of cytoplasmic NF- $\kappa \mathrm{B}$ into the

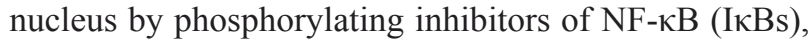
thus increasing the expression of genes involved in cancer progression [94]. Mechtler et al. used a luciferase reporter assay to confirm that IKK $\beta$ mRNA 3'-UTR harbors a miR497 binding site, and miR-497 transfection into C6TA4 cells resulted in a notable reduction in IKK $\beta$ protein level [50]. In prostate cancer, the suppression of IKK $\beta /$ CDK8/MMP-9 signaling via miR-497 over-expression led to nearly $50 \%$ inhibition of PC3-AR cell migration and invasion [95]. As described above, NF- $\kappa \mathrm{B}$ directly inhibits miR-497 transcription [49]. Therefore, miR-497 and the NF- $\kappa$ B pathway form a mutually inhibitory miR-497IKK $\beta$-IкBs-NF-кB-miR-497 feedback loop. (Figure 1)

TARBP2 and DICER play central roles in the miRNAs process by cleaving pre-miRNAs to form mature miRNAs. However, Caramuta et al. reported that miR497 could down-regulate these factors in NCI-H295R ACC cells [96]. In this study, significant enrichment of endogenous mRNAs was observed for both genes in immunoprecipitated Ago2 complexes when miR-497 was over-expressed, indicating that they are direct targets of miR-497. Therefore, the relevant negative feedback loop may involve mutual control of miR-497 and TARBP2/ DICER.

Several other genes critical to cancer genesis and progression are exclusive targets of miR-497. These genes include Nrdp1 [34], CHEK1 [28], FGF2, FGFR1 [29], BIRC5, WNT7A [10], HDGF [16], MEK1 [97], SMURF1 [98], WEE1 [99], ANLN and HSPA4 L [65], PDCD4 [40], AMOT [100], YAP1 [101], mTOR and p70S6K1 [102]. The miR-497 targets discovered in different cancers are summarized in Table 1.

\section{CLINICAL APPLICATIONS}

\section{miR-497 as a diagnostic marker}

Because miR-497 influences a wide range of tumor processes and is often deregulated in various cancers, it has potential use as a diagnostic biomarker.

Patients with breast cancer exhibit lower miR497 levels in tumor tissues compared with normal tissues $(p<0.0001)$ [15]. A recent report suggests that miR-497 is significantly up-regulated in typical lung carcinoids compared with atypical lung carcinoids [103]. Additionally, Feinmesser et al. confirmed that a combination of miR-34a and miR-497, both underexpressed in ACC, can discriminate these tumors from adrenocortical adenomas with a sensitivity of $89 \%$ and specificity of $100 \%$ [104]. Except for in tumor tissues, the circulating miR-497 level can also serve as a biomarker. $\mathrm{Du}$ et al. analyzed plasma from 175 bladder cancer patients and 185 healthy controls and found that plasma mir-479, the only significantly down-regulated miRNA at the validation phase, can distinguish bladder cancer patients from healthy controls [19]. Circulating miR497 could also be used as a diagnostic biomarker in astrocytomas [14], nasopharyngeal carcinoma [65] and acute myocardial infarction [105]. In general, more advanced or malignant tumors express lower levels of miR-497. For example, miR-497 is negatively correlated with lymph node metastasis and TNM stage in breast cancer [66], and cervical cancer patients with a high FIGO stage have lower miR-497 levels [33].

miR-497 is a widely expressed miRNA in a variety of normal tissues. So its clinical diagnostic worth of miR497 should be reconsidered, because its level in plasma may be influenced by a lot of physiological or pathological factors besides cancer. 


\section{miR-497 as a prognostic marker}

If miR-497 expression is related to cancer progression, its level can be used as a prognostic biomarker. Our lab analyzed data from 90 pancreatic cancers cases and found that a low miR-497 level was an independent negative prognostic factor for survival in pancreatic ductal adenocarcinoma (PDAC) [29]. Furthermore, in a study of 128 breast cancer patients, Wang et al. found that patients with high miR-497 expression had better 5-year disease-free and overall survival compared with patients with low miR-497 expression [106]. Similar findings have been reported in clear cell renal cell carcinoma [17], OC [98], retinoblastoma [99] and melanoma [31]. Conversely, a low miR-497 level in NSCLC is associated with poor survival and $\mathrm{pT}$ staging but has no significant correlation with pathologic type, $\mathrm{pN}$ staging or differentiation [102].

Strikingly, in a national, multicenter, pilot clinical trial, primary plasma cell leukemia patients who failed to respond to frontline therapy showed a significantly higher miR-497 level compared with responders, indicating that miR-497 can also be used to predict curative effects [107]. It is also possible that miR-497 may serve as a measure of therapeutic response or disease recurrence, though no study to date has validated this possibility.

\section{Potential therapeutic target}

miRNAs have gained increasing attention from researchers worldwide for their known post-transcriptional silencing effects.

In this review, we describe miR-497 as mainly a tumor suppressor gene. These data support an inspiring idea that elevated miR-497 can provide a novel therapeutic approach to inhibit multiple proteins involved in the formation and progression of cancer. In pancreatic cancer, mice transplanted with SW1990 cells that stably overexpressed miR-497 showed a tumor size reduction of more than $50 \%$ in 30 days [29]. In addition, Zhao et al. found that miR-497 up-regulation in NSCLC cells significantly reduced xenograft tumor volume, weight and angiogenesis by targeting HDGF [16]. Moreover, when LV-miR-497transfected Huh7 hepatoma cells were injected into the tail vein of nude mice, the number of metastatic lung nodules decreased markedly after four weeks compared with controls [67]. In prostate cancer, knocking down the expression of IKK $\beta$, a direct target of miR-497, can suppress cell proliferation, migration and invasion in vitro; this indicates that miR-497 targets also have therapeutic potential [95]. Notably, Li et al. directly injected an adenovirus-miR-497 sponge that could inhibit miR-497 expression into the left ventricular myocardium of mice 3 days before the onset of ischemia/reperfusion; they found a significant reduction in myocardial infarct size compared with controls [108].

miR-497 can also increase the sensitivity and response of tumor cells to drugs, and several reports suggest using it with chemotherapeutic agents. In osteosarcoma, Shao et al. found that cisplatin-induced cytotoxicity was markedly increased in SAOS-2 cells with enhanced miR-497 expression. Mice that received miR-497 and cisplatin combination therapy had smaller tumors than those given cisplatin alone, with reductions of more than $50 \%$ [72]. Consistently, enhanced miR497 expression promoted tumor chemosensitivity to gemcitabine in PDAC [64], cisplatin in chemotherapyresistant $\mathrm{OC}$ [59], 5-fluorouracil in CRC [36], and rituximab in DLBCL [41]. However, Lan et al. revealed that over-expressed miR-497 in glioma promoted chemotherapy resistance in glioma cells by targeting PDCD4 [40]. Therefore, appropriate treatment strategies should be chosen according to the specific functions of miR-497 in different cancers.

The intricate relationship between miR-497 and its downstream targets presents some risks when using miR497 as a therapeutic tool. The most prominent risk is the serious adverse effects of off-target activity or altering miR-497 levels in normal, non-cancerous cells. There are also other issues with miR-497 use, such as the targeted delivery and stability of drugs.

\section{CONCLUSIONS}

miR-497 is dysregulated in various cancers via a variety of mechanisms, including TFs, epigenetic alterations and genomic alterations. It acts as a key modulator of proliferation, differentiation, apoptosis, angiogenesis, migration and invasion. miR-497 functions mainly as a tumor suppressor gene. However, it also acts as an oncogene in different cancers by directly targeting various downstream genes and multiple signaling pathways. Increasing evidence indicates that miRNA-497 can serve as a diagnostic and prognostic biomarker and as a promising therapeutic target in future clinical application. Regardless, several issues require further investigation, such as the specificity for tumors as a diagnostic biomarker, adverse off-target effects, targeting infusion pathway and so on. There is a long way for application. Only a better understanding of miR-497 and its target genes will allow the successful translation of current research into clinical applications.

\section{ACKNOWLEDGMENTS}

This study was supported by grants from the National Science \& Technology Pillar Program during the Twelfth Five-year Plan Period (No. 2014BAI09B11), the Major State Basic Research Development Program of China (973 Program, No. 2014CB542300) the National Natural Science Foundation of China (No. 81272484) and 
The Research Special Fund for Public Welfare Industry of Health projects (No. 201402001). Competing financial interests: The authors declare that they have no competing interests.

\section{Author contributions}

T.Z. and Y.Z. contributed to the conception and design of the study, G.Y., G.X. and Z.C. wrote the main text, L.Y. and S.Z. prepared the figures. All authors reviewed the manuscript. G.Y., G.X. and Z.C. contributed equally to this work.

\section{REFERENCES}

1. Bartel DP. MicroRNAs: genomics, biogenesis, mechanism, and function (Reprinted from Cell 116 (2004) 281-297). Cell. 2007; 131: 11-29.

2. Lee Y, Ahn C, Han JJ, Choi H, Kim J, Yim J, Lee J, Provost P, Radmark O, Kim S, Kim VN. The nuclear RNase III Drosha initiates microRNA processing. Nature. 2003; 425: 415-419.

3. Bernstein E, Caudy AA, Hammond SM, Hannon GJ. Role for a bidentate ribonuclease in the initiation step of RNA interference. Nature. 2001; 409: 363-366.

4. Bohnsack MT, Czaplinski K, Gorlich D. Exportin 5 is a RanGTP-dependent dsRNA-binding protein that mediates nuclear export of pre-miRNAs. RNA. 2004; 10: 185-191.

5. Hutvagner G, McLachlan J, Pasquinelli AE, Balint E, Tuschl T, Zamore PD. A cellular function for the RNAinterference enzyme Dicer in the maturation of the let-7 small temporal RNA. Science. 2001; 293: 834-838.

6. Winter J, Jung S, Keller S, Gregory RI, Diederichs S. Many roads to maturity: microRNA biogenesis pathways and their regulation. Nat Cell Biol. 2009; 11: 228-234.

7. Mourelatos Z, Dostie J, Paushkin S, Sharma A, Charroux B, Abel L, Rappsilber J, Mann M, Dreyfuss G. miRNPs: a novel class of ribonucleoproteins containing numerous microRNAs. Genes Dev. 2002; 16: 720-728.

8. Gregory RI, Chendrimada TP, Cooch N, Shiekhattar R. Human RISC couples microRNA biogenesis and posttranscriptional gene silencing. Cell. 2005; 123: 631640.

9. Ruan K, Fang XG, Ouyang GL. MicroRNAs: novel regulators in the hallmarks of human cancer. Cancer Lett. 2009; 285: 116-126.

10. Itesako T, Seki N, Yoshino H, Chiyomaru T, Yamasaki T, Hidaka H, Yonezawa T, Nohata N, Kinoshita T, Nakagawa $\mathrm{M}$, Enokida $\mathrm{H}$. The microRNA expression signature of bladder cancer by deep sequencing: the functional significance of the miR-195/497 cluster. Plos One. 2014; 9: e84311.

11. Finnerty JR, Wang WX, Hebert SS, Wilfred BR, Mao GG, Nelson PT. The miR-15/107 group of microRNA genes: evolutionary biology, cellular functions, and roles in human diseases. J Mol Biol. 2010; 402: 491-509.

12. Aqeilan RI, Calin GA, Croce CM. miR-15a and miR-16-1 in cancer: discovery, function and future perspectives. Cell Death Diff. 2010; 17: 215-220.

13. He JF, Luo YM, Wan XH, Jiang DQ. Biogenesis of MiRNA-195 and its role in biogenesis, the cell cycle, and apoptosis. J Biochem Mol Toxicol. 2011; 25: 404-408.

14. Yang $\mathrm{CH}$, Wang $\mathrm{C}$, Chen $\mathrm{X}$, Chen SD, Zhang YN, Zhi F, Wang JJ, Li LM, Zhou XJ, Li NY, Pan H, Zhang JF, Zen $\mathrm{K}$, et al. Identification of seven serum microRNAs from a genome-wide serum microRNA expression profile as potential noninvasive biomarkers for malignant astrocytomas. Int J Cancer. 2013; 132: 116-127.

15. Li D, Zhao YL, Liu CX, Chen XN, Qi YT, Jiang Y, Zou C, Zhang XL, Liu SY, Wang XJ, Zhao D, Sun QA, Zeng ZB, et al. Analysis of MiR-195 and MiR-497 expression, regulation and role in breast cancer. Clin Cancer Res. 2011; 17: $1722-1730$.

16. Zhao W-y, Wang Y, An Z-j, Shi C-g, Zhu G-a, Wang B, Lu M-y, Pan C-k, Chen P. Downregulation of miR-497 promotes tumor growth and angiogenesis by targeting HDGF in non-small cell lung cancer. Biochem Biophys Res Commun. 2013; 435: 466-471.

17. Zhao XL, Zhao ZH, Xu WC, Hou JQ, Du XY. Downregulation of miR-497 is associated with poor prognosis in renal cancer. Int J Clin Exp Pathol. 2015; 8: 758-764.

18. Guo JM, Miao Y, Xiao BX, Huan R, Jiang Z, Meng D, Wang YJ. Differential expression of microRNA species in human gastric cancer versus non-tumorous tissues. J Gastroenterol Hepatol. 2009; 24: 652-657.

19. Du ML, Shi DN, Yuan L, Li PC, Chu HY, Qin C, Yin CJ, Zhang ZD, Wang ML. Circulating miR-497 and miR-663b in plasma are potential novel biomarkers for bladder cancer. Sci Rep. 2015; 5: 10437.

20. Yan LX, Huang XF, Shao Q, Huang MY, Deng L, Wu QL, Zeng YX, Shao JY. MicroRNA miR-21 overexpression in human breast cancer is associated with advanced clinical stage, lymph node metastasis and patient poor prognosis. RNA. 2008; 14: 2348-2360.

21. Tahiri A, Leivonen SK, Luders T, Steinfeld I, Aure MR, Geisler J, Makela R, Nord S, Riis MLH, Yakhini Z, Sahlberg KK, Borresen-Dale AL, Perala M, et al. Deregulation of cancer-related miRNAs is a common event in both benign and malignant human breast tumors. Carcinogenesis. 2014; 35: 76-85.

22. Luo QF, Li XY, Gao Y, Long Y, Chen L, Huang YX, Fang L. MiRNA-497 regulates cell growth and invasion by targeting cyclin E1 in breast cancer. Cancer Cell Int. 2013; 13: 95 .

23. Chang YY, Kuo WH, Hung JH, Lee CY, Lee YH, Chang YC, Lin WC, Shen CY, Huang CS, Hsieh FJ, Lai LC, Tsai $\mathrm{MH}$, Chang KJ, et al. Deregulated microRNAs in triplenegative breast cancer revealed by deep sequencing. Mol 
Cancer. 2015; 14: 36.

24. Lehmann U, Streichert T, Otto B, Albat C, Hasemeier B, Christgen H, Schipper E, Hille U, Kreipe HH, Langer F. Identification of differentially expressed microRNAs in human male breast cancer. BMC Cancer. 2010; 10: 109.

25. Pinto R, De Summa S, Danza K, Popescu O, Paradiso A, Micale L, Merla G, Palumbo O, Carella M, Tommasi S. MicroRNA expression profiling in male and female familial breast cancer. Br J Cancer. 2014; 111: 2361-2368.

26. Li WD, Jin XJ, Deng XB, Zhang G, Zhang BQ, Ma L. The putative tumor suppressor microRNA-497 modulates gastric cancer cell proliferation and invasion by repressing eIF4E. Biochem Biophys Res Commun. 2014; 449: 235240.

27. Menigatti $\mathrm{M}$, Staiano $\mathrm{T}$, Manser $\mathrm{CN}$, Bauerfeind $\mathrm{P}$, Komljenovic A, Robinson M, Jiricny J, Buffoli F, Marra G. Epigenetic silencing of monoallelically methylated miRNA loci in precancerous colorectal lesions. Oncogenesis. 2013; 2: e56.

28. Xie Y, Wei R-R, Huang G-L, Zhang M-Y, Yuan Y-F, Wang $\mathrm{H}-\mathrm{Y}$. Checkpoint kinase 1 is negatively regulated by miR497 in hepatocellular carcinoma. Med Oncol. 2014; 31: 844.

29. Xu J, Wang T, Cao Z, Huang H, Li J, Liu W, Liu S, You L, Zhou L, Zhang T, Zhao Y. MiR-497 downregulation contributes to the malignancy of pancreatic cancer and associates with a poor prognosis. Oncotarget. 2014; 5: 6983-6993. doi: 10.18632/oncotarget.2184.

30. Ozata DM, Caramuta S, Velazquez-Fernandez D, Akcakaya P, Xie H, Hoog A, Zedenius J, Backdahl M, Larsson C, Lui WO. The role of microRNA deregulation in the pathogenesis of adrenocortical carcinoma. Endocr Relat Cancer. 2011; 18: 643-655.

31. Kunz M. (2013). MicroRNAs in melanoma biology. In: Schmitz U, Wolkenhauer O and Vera J, eds. Microrna cancer regulation: advanced concepts, bioinformatics and systems biology tools. (Dordrecht: Springer), pp. 103-120.

32. Delfino KR, Rodriguez-Zas SL. Transcription factormicroRNA-target gene networks associated with ovarian cancer survival and recurrence. Plos One. 2013; 8: e58608.

33. Luo M, Shen DX, Zhou XN, Chen XD, Wang W. MicroRNA-497 is a potential prognostic marker in human cervical cancer and functions as a tumor suppressor by targeting the insulin-like growth factor 1 receptor. Surgery. 2013; 153: 836-847.

34. Jiang YS, Meng QH, Qi JQ, Shen HY, Sun SC. MiR-497 promotes metastasis of colorectal cancer cells through Nrdp1 inhibition. Tumour Biol. 2015; 36: 7641-7647.

35. Guo ST, Jiang CC, Wang GP, Li YP, Wang CY, Guo XY, Yang RH, Feng Y, Wang FH, Tseng HY, Thorne RF, Jin L, Zhang XD. MicroRNA-497 targets insulin-like growth factor 1 receptor and has a tumour suppressive role in human colorectal cancer. Oncogene. 2013; 32: 1910-1920.

36. Wang L, Jiang CF, Li DM, Ge X, Shi ZM, Li CY, Liu
X, Yin Y, Zhen LL, Liu LZ, Jiang BH. MicroRNA-497 inhibits tumor growth and increases chemosensitivity to 5-fluorouracil treatment by targeting KSR1. Oncotarget. 2016; 7: 2660-2671. doi: 10.18632/oncotarget.6545.

37. Qiu YY, Hu Q, Tang QF, Feng W, Hu SJ, Liang B, Peng W, Yin PH. MicroRNA-497 and bufalin act synergistically to inhibit colorectal cancer metastasis. Tumour Biol. 2014; 35: 2599-2606.

38. Zhang YJ, Zhang DH, Wang F, Xu DF, Guo Y, Cui W. Serum miRNAs panel (miR-16-2*, miR-195, miR-2861, miR-497) as novel non-invasive biomarkers for detection of cervical cancer. Sci Rep. 2015; 5: 17942.

39. Maura F, Cutrona G, Mosca L, Matis S, Lionetti M, Fabris S, Agnelli L, Colombo M, Massucco C, Ferracin M, Zagatti B, Reverberi D, Gentile M, et al. Association between gene and miRNA expression profiles and stereotyped subset \#4 B-cell receptor in chronic lymphocytic leukemia. Leuk Lymphoma. 2015; 56: 3150-3158.

40. Lan J, Xue YJ, Chen HR, Zhao SH, Wu ZJ, Fang J, Han C, Lou MQ. Hypoxia-induced miR-497 decreases glioma cell sensitivity to TMZ by inhibiting apoptosis. FEBS Lett. 2014; 588: 3333-3339.

41. Troppan K, Wenzl K, Pichler M, Pursche B, Schwarzenbacher D, Feichtinger J, Thallinger GG, Beham-Schmid C, Neumeister P, Deutsch A. miR-199a and miR-497 are associated with better overall survival due to increased chemosensitivity in diffuse large B-cell lymphoma patients. Int J Mol Sci. 2015; 16: 18077-18095.

42. Slattery M, Zhou TY, Yang L, Machado ACD, Gordan R, Rohs R. Absence of a simple code: how transcription factors read the genome. Trends Biochem Sci. 2014; 39: 381-399.

43. Kulshreshtha R, Ferracin M, Wojcik SE, Garzon R, Alder H, Agosto-Perez FJ, Davuluri R, Liu CG, Croce CM, Negrini M, Calin GA, Ivan M. A microRNA signature of hypoxia. Mol Cell Biol. 2007; 27: 1859-1867.

44. Goda N, Ryan HE, Khadivi B, McNulty W, Rickert RC, Johnson RS. Hypoxia-inducible factor 1 alpha is essential for cell cycle arrest during hypoxia. Mol Cell Biol. 2003; 23: 359-369.

45. Xu XF, Jia RB, Zhou YX, Song X, Wang J, Qian GX, Ge SF, Fan XQ. Microarray-based analysis: identification of hypoxia-regulated microRNAs in retinoblastoma cells. Int J Oncol. 2011; 38: 1385-1393.

46. Wu ZH, Cai XH, Huang CG, Xu J, Liu A. miR-497 suppresses angiogenesis in breast carcinoma by targeting HIF-1 alpha. Oncol Rep. 2016; 35: 1696-1702.

47. Chen LF, Greene WC. Shaping the nuclear action of NFkappa B. Nat Rev Mol Cell Biol. 2004; 5: 392-401.

48. Taganov KD, Boldin MP, Chang KJ, Baltimore D. NFkappa B-dependent induction of microRNA miR-146, an inhibitor targeted to signaling proteins of innate immune responses. Proc Natl Acad Sci USA. 2006; 103: 1248112486. 
49. Wei W, Zhang WY, Bai JB, Zhang HX, Zhao YY, Li XY, Zhao SH. The NF-kappa B-modulated microRNAs miR195 and miR-497 inhibit myoblast proliferation by targeting Igflr, Insr and cyclin genes. J Cell Sci. 2016; 129: 39-50.

50. Mechtler P, Singhal R, Kichina JV, Bard JE, Buck MJ, Kandel ES. MicroRNA analysis suggests an additional level of feedback regulation in the NF-kappa B signaling cascade. Oncotarget. 2015; 6: 17097-17106. doi: 10.18632/ oncotarget.4005.

51. Liu XL, Chen XY, Yu XF, Tao YG, Bode AM, Dong ZG, Cao Y. Regulation of microRNAs by epigenetics and their interplay involved in cancer. J Exp Clin Cancer Res. 2013; 32: 8 .

52. Lopez-Serra P, Esteller M. DNA methylation-associated silencing of tumor-suppressor microRNAs in cancer. Oncogene. 2012; 31: 1609-1622.

53. Dominguez-Salas $\mathrm{P}$, Moore SE, Cole D, da Costa KA, Cox SE, Dyer RA, Fulford AJC, Innis SM, Waterland RA, Zeisel SH, Prentice AM, Hennig BJ. DNA methylation potential: dietary intake and blood concentrations of onecarbon metabolites and cofactors in rural African women. Am J Clin Nutr. 2013; 97: 1217-1227.

54. Cook RJ, Wagner C. Glycine N-methyltransferase is a folate binding-protein of rat-liver cytosol. Proc Natl Acad Sci USA. 1984; 81: 3631-3634.

55. Storch KJ, Wagner DA, Young VR. Methionine kinetics in adult men - effects of dietary betaine on L- H-2(3)-methyl1-C-13 methionine. Am J Clin Nutr. 1991; 54: 386-394.

56. Varela-Rey M, Martinez-Lopez N, Fernandez-Ramos D, Embade N, Calvisi DF, Woodhoo A, Rodriguez J, Fraga MF, Julve J, Rodriguez-Millan E, Frades I, Torres L, Luka Z, et al. Fatty liver and fibrosis in glycine $\mathrm{N}$-methyltransferase knockout mice is prevented by nicotinamide. Hepatology. 2010; 52: 105-114.

57. Cai DM, Jia YM, Lu JY, Yuan MJ, Sui SY, Song HG, Zhao RQ. Maternal dietary betaine supplementation modifies hepatic expression of cholesterol metabolic genes via epigenetic mechanisms in newborn piglets. Br J Nutr. 2014; 112: 1459-1468.

58. He XX, Kuang SZ, Liao JZ, Xu CR, Chang Y, Wu YL, Gong J, Tian DA, Guo AY, Lin JS. The regulation of microRNA expression by DNA methylation in hepatocellular carcinoma. Mol Biosyst. 2015; 11: 532-539.

59. Xu SH, Fu GB, Tao Z, OuYang J, Kong FF, Jiang BH, Wan XP, Chen K. MiR-497 decreases cisplatin resistance in ovarian cancer cells by targeting mTOR/P70S6K1. Oncotarget. 2015; 6: 26457-26471. doi: 10.18632/ oncotarget.4762.

60. Flavin RJ, Smyth PC, Laios A, O'Toole SA, Barrett C, Finn SP, Russell S, Ring M, Denning KM, Li J, Aherne ST, Sammarae DA, Aziz NA, et al. Potentially important microRNA cluster on chromosome 17 p13.1 in primary peritoneal carcinoma. Mod Pathol. 2009; 22: 197-205.

61. Vaishnavi V, Manikandan M, Tiwary BK, Munirajan AK.
Insights on the functional impact of microRNAs present in autism-associated copy number variants. Plos One. 2013; 8: e56781.

62. Karreth FA, Tay Y, Perna D, Ala U, Tan SM, Rust AG, DeNicola G, Webster KA, Weiss D, Perez-Mancera PA, Krauthammer M, Halaban R, Provero P, et al. In vivo identification of tumor-suppressive PTEN ceRNAs in an oncogenic BRAF-induced mouse model of melanoma. Cell. 2011; 147: 382-395.

63. Salmena L, Poliseno L, Tay Y, Kats L, Pandolfi PP. A ceRNA hypothesis: the Rosetta Stone of a hidden RNA language? Cell. 2011; 146: 353-358.

64. Xu J-W, Wang T-X, You L, Zheng L-F, Shu H, Zhang T-P, Zhao Y-P. Insulin-like growth factor 1 receptor (IGF-1R) as a target of MiR-497 and plasma IGF-1R levels associated with TNM stage of pancreatic cancer. Plos One. 2014; 9: e92847.

65. Wang SM, Mo YX, Midorikawa K, Zhang Z, Huang GW, Ma N, Zhao WL, Hiraku Y, Oikawa S, Murata M. The potent tumor suppressor miR-497 inhibits cancer phenotypes in nasopharyngeal carcinoma by targeting ANLN and HSPA4L. Oncotarget. 2015; 6: 35893-35907. doi: 10.18632/oncotarget.5651.

66. Shen L, Li J, Xu JP, Ma J, Li H, Xiao XG, Zhao JY, Fang L. miR-497 induces apoptosis of breast cancer cells by targeting Bcl-w. Exp Ther Med. 2012; 3: 475-480.

67. Yan J-J, Zhang Y-N, Liao J-Z, Ke K-p, Chang Y, Li P-Y, Wang M, Lin J-S, He X-X. MiR-497 suppresses angiogenesis and metastasis of hepatocellular carcinoma by inhibiting VEGFA and AEG-1. Oncotarget. 2015; 6: 29527 29542. doi: 10.18632/oncotarget.5012.

68. Wang W, Ren F, Wu QH, Jiang DZ, Li HJ, Shi HR. MicroRNA-497 suppresses angiogenesis by targeting vascular endothelial growth factor A through the PI3K/ AKT and MAPK/ERK pathways in ovarian cancer. Oncol Rep. 2014; 32: 2127-2133.

69. Wei CK, Luo QF, Sun XG, Li DF, Song HM, Li XY, Song JL, Hua KY, Fang L. microRNA-497 induces cell apoptosis by negatively regulating $\mathrm{Bcl}-2$ protein expression at the posttranscriptional level in human breast cancer. Int J Clin Exp Pathol. 2015; 8: 7729-7739.

70. Wang L, Li B, Li L, Wang T. MicroRNA-497 suppresses proliferation and induces apoptosis in prostate cancer cells. Asian Pac J Cancer Prev. 2013; 14: 3499-3502.

71. Gu AQ, Lu JH, Wang WM, Shi CL, Han BH, Yao M. Role of miR-497 in VEGF-A-mediated cancer cell growth and invasion in non-small cell lung cancer. Int J Biochem Cell Biol. 2016; 70: 118-125.

72. Shao XJ, Miao MH, Xue J, Ji XQ, Zhu H. The downregulation of microRNA-497 contributes to cell growth and cisplatin resistance through PI3K/Akt pathway in osteosarcoma. Cell Physiol Biochem. 2015; 36: 2051-2062.

73. Farazi TA, Hoell JI, Morozov P, Tuschl T. MicroRNAs in human cancer. Adv Exp Med Biol. 2013; 774: 1-20. 
74. Bartel DP. MicroRNAs: genomics, biogenesis, mechanism, and function. Cell. 2004; 116: 281-297.

75. Siddiqui WA, Ahad A, Ahsan H. The mystery of BCL2 family: Bcl-2 proteins and apoptosis: an update. Arch Toxicol. 2015; 89: 289-317.

76. Yin KJ, Deng Z, Huang HR, Hamblin M, Xie CQ, Zhang JF, Chen YE. miR-497 regulates neuronal death in mouse brain after transient focal cerebral ischemia. Neurobiol Dis. 2010; 38: 17-26.

77. Zhu W, Zhu DX, Lu SQ, Wang TS, Wang J, Jiang BH, Shu YQ, Liu P. miR-497 modulates multidrug resistance of human cancer cell lines by targeting BCL2. Med Oncol. 2012; 29: 384-391.

78. Um HD. Bcl-2 family proteins as regulators of cancer cell invasion and metastasis: a review focusing on mitochondrial respiration and reactive oxygen species. Oncotarget. 2015; 7: 5193-5203. doi: 10.18632/oncotarget.6405.

79. Saharinen P, Eklund L, Pulkki K, Bono P, Alitalo K. VEGF and angiopoietin signaling in tumor angiogenesis and metastasis. Trends Mol Med. 2011; 17: 347-362.

80. Paez-Ribes M, Allen E, Hudock J, Takeda T, Okuyama H, Vinals F, Inoue M, Bergers G, Hanahan D, Casanovas O. Antiangiogenic therapy elicits malignant progression of tumors to increased local invasion and distant metastasis. Cancer Cell. 2009; 15: 220-231.

81. Tu Y, Liu L, Zhao D, Liu Y, Ma X, Fan Y, Wan L, Huang T, Cheng Z, Shen B. Overexpression of miRNA-497 inhibits tumor angiogenesis by targeting VEGFR2. Sci Rep. 2015; 5: 13827

82. Dupont J, LeRoith D. Insulin and insulin-like growth factor I receptors: similarities and differences in signal transduction. Horm Res. 2001; 55: 22-26.

83. Shen MR, Hsu YM, Hsu KF, Chen YF, Tang MJ, Chou CY. Insulin-like growth factor 1 is a potent stimulator of cervical cancer cell invasiveness and proliferation that is modulated by alpha(v)beta(3) integrin signaling. Carcinogenesis. 2006; 27: 962-971.

84. Singh P, Alex JM, Bast F. Insulin receptor (IR) and insulinlike growth factor receptor 1 (IGF-1R) signaling systems: novel treatment strategies for cancer. Med Oncol. 2014; 31: 805 .

85. Wang $X$, Wang MC, Li HM, Lan X, Liu L, Li JX, Li Y, Li J, Yi J, Du XJ, Yan JD, Han Y, Zhang FJ, et al. Upregulation of miR-497 induces hepatic insulin resistance in E3 rats with HFD-MetS by targeting insulin receptor. Mol Cell Endocrinol. 2015; 416: 57-69.

86. Rosenberg E, Demopoulos RI, Zeleniuch-Jacquotte A, Yee H, Sorich J, Speyer JL, Newcomb EW. Expression of cell cycle regulators p57(KIP2), cyclin D1, and cyclin E in epithelial ovarian tumors and survival. Hum Pathol. 2001; 32: 808-813.

87. Möröy T, Geisen C. Cyclin E. Int J Biochem Cell Biol. 2004; 36: 1424-1439.

88. Schraml P, Bucher C, Bissig H, Nocito A, Haas P, Wilber
K, Seelig S, Kononen J, Mihatsch MJ, Dirnhofer S, Sauter G. Cyclin E overexpression and amplification in human tumours. J Pathol. 2003; 200: 375-382.

89. Furuta M, Kozaki K, Tanimoto K, Tanaka S, Arii S, Shimamura T, Niida A, Miyano S, Inazawa J. The tumorsuppressive miR-497-195 cluster targets multiple cell-cycle regulators in hepatocellular carcinoma. Plos One. 2013; 8: e60155.

90. Han ZY, Zhang YB, Yang QY, Liu BB, Wu JJ, Zhang YJ, Yang CF, Jiang YG. miR-497 and miR-34a retard lung cancer growth by co-inhibiting cyclin E1 (CCNE1). Oncotarget. 2015; 6: 13149-13163. doi: 10.18632/ oncotarget.3693.

91. Yadav S, Pandey A, Shukla A, Talwelkar SS, Kumar A, Pant AB, Parmar D. miR-497 and miR-302b Regulate Ethanol-induced Neuronal Cell Death through BCL2 Protein and Cyclin D2. J Biol Chem. 2011; 286: $37347-$ 37357.

92. Sato T, Yamamoto T, Sehara-Fujisawa A. miR-195/497 induce postnatal quiescence of skeletal muscle stem cells. Nat Commun. 2014; 5: 4597.

93. Zandi E, Rothwarf DM, Delhase M, Hayakawa M, Karin M. The I kappa B kinase complex (IKK) contains two kinase subunits, IKK alpha and IKK beta, necessary for I kappa B phosphorylation and NF-kappa B activation. Cell. 1997; 91: 243-252.

94. Maeda S, Omata M. Inflammation and cancer: role of nuclear factor-kappaB activation. Cancer Sci. 2008; 99: 836-842.

95. Kong XJ, Duan LJ, Qian XQ, Xu D, Liu HL, Zhu YJ, Qi J. Tumor-suppressive microRNA-497 targets IKK beta to regulate NF-kappa B signaling pathway in human prostate cancer cells. Am J Cancer Res. 2015; 5: 1795-1804.

96. Caramuta S, Lee L, Ozata DM, Akcakaya P, Xie H, Hoog A, Zedenius J, Backdahl M, Larsson C, Lui WO. Clinical and functional impact of TARBP2 over-expression in adrenocortical carcinoma. Endocr Relat Cancer. 2013; 20: 551-564.

97. Zheng DL, Radziszewska A, Woo P. MicroRNA 497 modulates interleukin 1 signalling via the MAPK/ERK pathway. FEBS Lett. 2012; 586: 4165-4172.

98. Wang W, Ren F, Wu QH, Jiang DZ, Li HJ, Peng Z, Wang JL, Shi HR. MicroRNA-497 inhibition of ovarian cancer cell migration and invasion through targeting of SMAD specific E3 ubiquitin protein ligase 1. Biochem Biophys Res Commun. 2014; 449: 432-437.

99. Creevey L, Ryan J, Harvey H, Bray IM, Meehan M, Khan AR, Stallings RL. MicroRNA-497 increases apoptosis in MYCN amplified neuroblastoma cells by targeting the key cell cycle regulator WEE1. Mol Cancer. 2013; 12: 23.

100. Ruan WD, Wang P, Feng SQ, Xue Y, Zhang B. MicroRNA-497 inhibits cell proliferation, migration, and invasion by targeting AMOT in human osteosarcoma cells. Onco Targets Ther. 2016; 9: 303-313. 
101. Hao YW, Chun A, Cheung K, Rashidi B, Yang XL. Tumor suppressor LATS1 is a negative regulator of oncogene YAP. J Biol Chem. 2008; 283: 5496-5509.

102. Huang CB, Ma RJ, Yue J, Li N, Li ZX, Qi DL. MiR-497 suppresses YAP1 and inhibits tumor growth in non-small cell lung cancer. Cell Physiol Biochem. 2015; 37: 342-352.

103. Rapa I, Votta A, Felice B, Righi L, Giorcelli J, Scarpa A, Speel EJM, Scagliotti GV, Papotti M, Volante M. Identification of microRNAs differentially expressed in lung carcinoid subtypes and progression. Neuroendocrinology. 2015; 101: 246-255.

104. Feinmesser M, Benbassat C, Meiri E, Benjamin H, Lebanony D, Lebenthal Y, de Vries L, Drozd T, Spector Y. Specific microRNAs differentiate adrenocortical adenomas from carcinomas and correlate with Weiss histopathologic system. Appl Immunohistochem Mol Morphol. 2015; 23: 522-531.

105. Li ZC, Lu J, Luo Y, Li SN, Chen MS. High association between human circulating microRNA-497 and acute myocardial infarction. ScientificWorldJournal. 2014; 2014: 931845.
106. Wang SH, Li HJ, Wang JJ, Wang D. Expression of microRNA-497 and its prognostic significance in human breast cancer (Retracted article. See vol. 10, pg. 9, 2015). Diagn Pathol. 2013; 8: 9.

107. Lionetti M, Musto P, Di Martino MT, Fabris S, Agnelli L, Todoerti K, Tuana G, Mosca L, Cantafio MEG, Grieco V, Bianchino G, D'Auria F, Statuto T, et al. Biological and clinical relevance of miRNA expression signatures in primary plasma cell leukemia. Clin Cancer Res. 2013; 19: 3130-3142.

108. Li XX, Zeng Z, Li Q, Xu QL, Xie JH, Hao HX, Luo GJ, Liao WJ, Bin JP, Huang XB, Liao YL. Inhibition of microRNA-497 ameliorates anoxia/reoxygenation injury in cardiomyocytes by suppressing cell apoptosis and enhancing autophagy. Oncotarget. 2015; 6: 18829-18844. doi: 10.18632/oncotarget.4774.

109. Poell JB, van Haastert RJ, de Gunst T, Schultz IJ, Gommans WM, Verheul M, Cerisoli F, van Noort PI, Prevost GP, Schaapveld RQJ, Cuppen E. A functional screen identifies specific microRNAs capable of inhibiting human melanoma cell viability. Plos One. 2012; 7: e43569. 